\title{
PENGEMBANGAN MEDIA PEMBELAJARAN BERBASIS MOBILE LEARNING MENGGUNAKAN MODEL FOUR D UNTUK MATA KULIAH PEMOGRAMAN BERORIENTASI OBJEK DI AMIK BOEKITTINGGI
}

\author{
Geovanne Farell ${ }^{1}$ \\ Kasman Rukun ${ }^{2}$ \\ Waskito $^{3}$
}

\begin{abstract}
Based on preliminary analysis, the results of student learning object oriented programming courses show the numbers are still relatively low, the low expected learning outcomes is due to the limitations of learning resources or existing instructional media. This research was conducted using the method of research and development (R\&D) by using the Four- D model. The development of Mobile Learning used method Design of Exploratory Tutorial. The result of validity test shown that Mobile Learning media was valid. Then the result of practicalities test obtained also show the practicalities of media. Effectiveness of Mobile Learning media declared effective in improving student learning outcomes. Based on the findings of this study concluded that Mobile Learning was valid, practical, and effective to be used as media learning.
\end{abstract}

Keywords: Mobile, Learning, Smartphone, Validity, Effectiveness, Practicalities.

\section{INTISARI}

Berdasarkan analisis awal, hasil belajar mahasiswa mata kuliah Pemrograman Berorientasi Objek menunjukkan angka yang relatif masih rendah, diperkirakan rendahnya hasil belajar ini disebabkan oleh keterbatasan sumber belajar atau media pembelajaran yang ada. Tujuan penelitian ini adalah untuk merancang serta menguji validitas, praktikalitas, dan efektivitas Mobile Learning agar layak digunakan di lapangan. Penelitian ini dilaksanakan menggunakan metode penelitian dan pengembangan (Research and Development/ R\&D) dengan menggunakan model pengembangan Four-D. Perancangan Mobile Learning menggunakan metode Exploratory Tutorial. Uji validitas menunjukkan media pembelajaran Mobile Learning ini valid. Kemudian dilakukan uji praktikalitas, diperoleh juga hasilnya menunjukkan media ini praktis. Lalu dilakukan uji efektivitas dengan melihat hasil belajar mahasiswa yang menggunakan Mobile Learning, terdapat peningkatan hasil belajar setelah menggunakan media Mobile Learning. Berdasarkan temuan penelitian ini disimpulkan bahwa Mobile Learning ini valid, praktis, dan efektif untuk dimanfaatkan sebagai media pembelajaran.

Kata Kunci: Mobile, Learning, Smartphone, Media, Valid, Efektif, Praktis.

${ }^{123}$ Dosen Fakultas Teknik Universitas Negeri Padang 


\section{PENDAHULUAN}

Pendidikan jika dipandang sebagai suatu proses, maka di dalamnya terdapat tiga unsur pokok yang saling berkaitan, yaitu tujuan belajar,dan pengalaman belajar. Tujuan belajar mengacu pada falsafah negara yang dituangkan dalam kurikulum pendidikan dan dalam setiap kurikulum pendidikan telah dirumuskan tujuan setiap mata pelajaran serta tujuan instruksional secara umum setiap pokok bahasan. Pengalaman belajar adalah proses pembelajaran yang terjadi, mencakup pemilihan metode yang digunakan guru dalam menyampaikan materi, rencana kegiatan kelas, serta pencapaian target akhir yang dapat dicapai oleh peserta didik (Apriyanti, 2010:2).

Pembelajaran adalah sebuah proses interaksi antara peserta didik, pengajar dan bahan ajar. Komunikasi tidak akan berjalan tanpa bantuan sarana penyampai pesan atau media. Pesan yang akan dikomunikasikan adalah isi pembelajaran yang ada dalam kurikulum yang dituangkan oleh pengajar atau fasilitator atau sumber lain ke dalam simbol-simbol komunikasi, baik simbol verbal maupun simbol non verbal atau visual (Santyasa,2007:3).

Dunia pendidikan terus bergerak secara dinamis, khususnya untuk menciptakan media, metode, dan materi pendidikan yang semakin interaktif dan komperhensif. Media yang secara lazim tersedia antara lain: buku, majalah, jurnal, koran, tabloid untuk media offline, radio, TV, dan terakhir internet sebagai media online (Oetomo, 2002: 119).

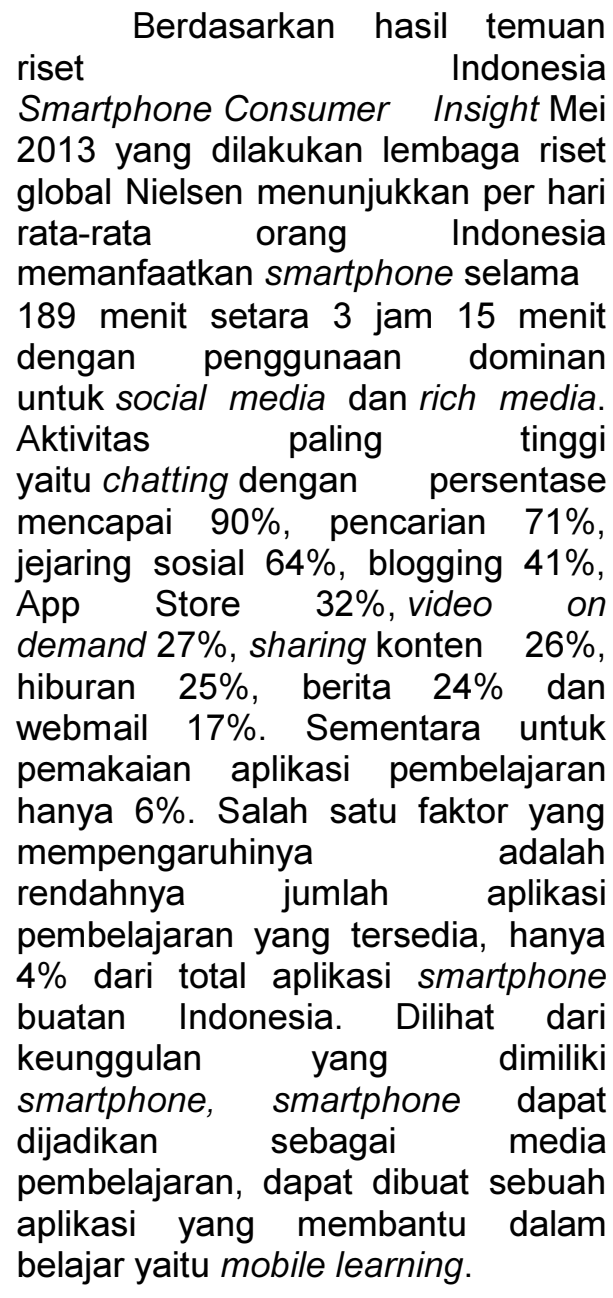

Mata kuliah Pemrograman Berorientasi Objek (PBO) adalah salah satu mata kuliah praktek yang diajarkan di Akademi Manajemen Informatika dan Komputer Boekittinggi. PBO merupakan paradigma pemrograman yang berorientasikan kepada objek. Semua data dan fungsi di dalam paradigma ini dibungkus dalam kelas-kelas atau objek-objek. Pembelajaran PBO menuntut mahasiswa untuk rajin dalam melakukan pengulangan materi, karena belajar PBO membutuhkan pembiasaan untuk memahami dan mempraktekkan Bahasa Pemrograman yang dipelajari. 
Pembelajaran PBO menggunakan modul-modul yang akan menuntun mahasiswa dalam pembuatan program. Penggunaan modul yang masih dalam bentuk hardcopy, menjadikan mahasiswa malas untuk memiliki modul tersebut sehingga minat mahasiswa dalam belajar praktek PBO berkurang. Berdasarkan hasil observasi sementara pada mata kuliah PBO di Akademi Manajemen Informatika dan Komputer Boekittinggi adalah terdapat sarana prasarana yang menunjang proses pembelajaran diantaranya ruang belajar yang nyaman untuk belajar, dan tersedianya infokus sebagai pemanfaatan untuk media pembelajaran.

Berdasarkan uraian diatas, maka dikembangkan sebuah mobile learning untuk mata kuliah PBO. Mobile learning yang akan dikembangkan untuk mata kuliah PBO menggunakan menggunakan model pengembangan media ajar Four-D (4D). Model 4D mempunyai tahapan: Define (Pendefinisian), Design (Perancangan), Develop (Pengembangan), dan Disseminate (Penyebarluasan).

\section{Metode}

Jenis penelitian yang dilakukan adalah Research and Development (R\&D) atau penelitian pengembangan. Menurut Putra (2012:67), metode penelitian dan pengembangan (Research and Development) adalah penelitian yang secara sengaja, sistematis, bertujuan/diarahkan untuk mencaritemukan, merumuskan, memperbaiki, mengembangkan, menghasilkan, menguji keefektifan produk, model, metode/strategi/cara, jasa, prosedur tertentu yang lebih unggul, baru, efektif, efisien, produktif, dan bermakna.

Model pengembangan yang digunakan dalam penelitian ini adalah model Four $D$ (4D). Menurut Thiagarajan, dkk (1974), 4D model ini terdiri dari 4 tahap pengembangan yaitu Define, Design, Develop, dan Disseminate atau diadaptasikan menjadi model 4-D, yaitu pendefinisian, perancangan, pengembangan, dan penyebaran.

\section{Hasil Penelitian dan}

\section{Pembahasan}

A. Hasil Penelitian

Validasi M-Learning diperoleh dari tanggapan validator tentang kevaliditasan M-Learning. Hasil dari angket validator dapat dilihat sebagai berikut:

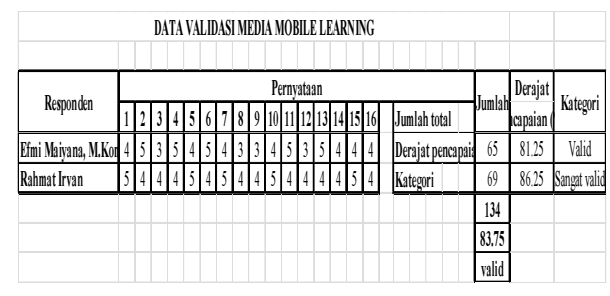

Gambar 1. Data Validasi Media $M$ Learning

Tanggapan-tanggapan

secara rata-rata yang diperoleh dari validator berdasarkan isian angket validasi mengenai $M$-Learning diperoleh tanggapan sangat setuju dan setuju, adapun untuk untuk jawaban cukup untuk validator pertama di dapatkan pada butir ketiga dikarenakan validator berpendapat latihan yang terdapat di dalam media 
mobile learning belum bisa menjadi tolak ukur kemampuan mahasiswa dikarenakan mata kuliah PBO adalah matakuliah gabungan teori dan praktek.

Praktikalitas $\quad M$ Learning diperoleh dari tanggapan praktisi tentang kepraktisan M-Learning. Praktisi terdiri dari 12 orang yaitu 2 orang dosen PBO dan 10 orang mahasiswa AMIK Boekittinggi. Sebelum Dosen PBO menggunakan media, dosen PBO diajarkan cara menggunakannya serta diberikan buku petunjuk penggunaannya. Tanggapantanggapan yang diperoleh dari dosen PBO yang didapatkan dari isian angket praktikalitas mengenai M-Learning diperoleh tanggapan antara cukup, setuju dan sangat setuju.

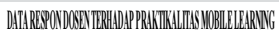

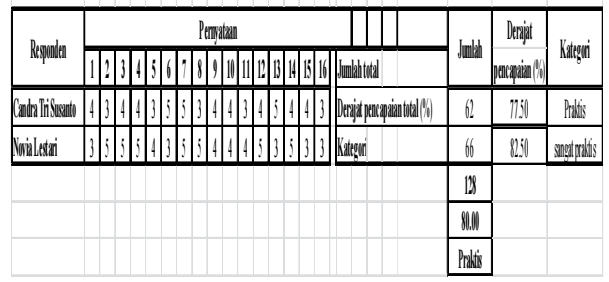

Gambar 2. Data Praktikalitas Dosen terhadap Media M-Learning

Sedangkan tanggapantanggapan yang diperoleh dari mahasiswa yang didapatkan dari isian angket praktikalitas mengenai M-Learning diperoleh tanggapan sebagian besar setuju dan sangat setuju serta hanya sebagian kecil mahasiswa yang memberikan cukupterhadap pernyataanpernyataan yang telah disediakan. Data derajat pencapaian untuk mahasiswa menunjukkan angka $81.37 \%$, yang berarti media mobile learning ini dinilai praktis.

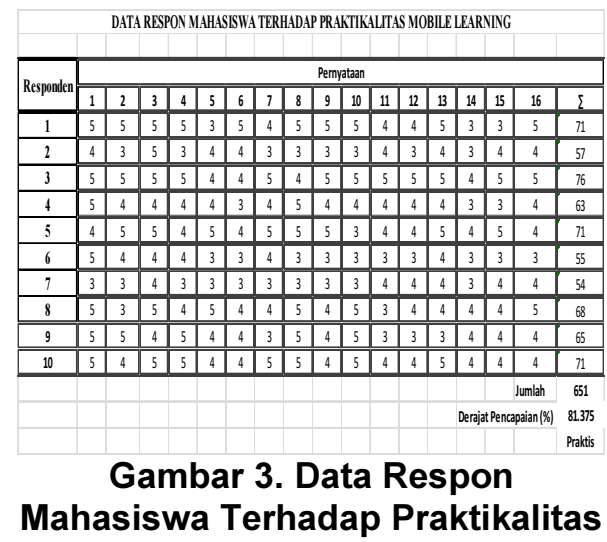

Efektivitas $M$-Learning diperoleh dari hasil pencapaian hasil belajar mahasiswa setelah menggunakan $M$ Learning. Hasil belajar mahasiswa dilihat sebelum menggunakan $M$-Learning dan setelah menggunakan $M$ Learning. Rata-rata hasil belajar ini diambil pada kompetensi dasar Graphical User Interface pada windows matakuliah Pemrograman Berorientasi Objek. Hasil belajar didapatkan dari hasil tes 10 orang mahasiswa. Berikut adalah rata-rata hasil belajar mahasiswa sebelum menggunakan M-Learning:

Tabel 1. Rata-rata hasil belajar mahasiswa sebelum menggunakan M-Learning

\begin{tabular}{|c|l|c|c|c|}
\hline $\begin{array}{c}\mathbf{N} \\
\text { o. }\end{array}$ & $\begin{array}{c}\text { Nama } \\
\text { Mahasisw } \\
\text { a }\end{array}$ & $\begin{array}{c}\text { Hasil } \\
\text { Belaj } \\
\text { ar }\end{array}$ & $\begin{array}{c}\text { KK } \\
\mathbf{M}\end{array}$ & $\begin{array}{c}\text { Keterang } \\
\text { an }\end{array}$ \\
\hline 1. & $\begin{array}{l}\text { Riko } \\
\text { Ardian }\end{array}$ & 68 & 75 & Tidak \\
\hline
\end{tabular}




\begin{tabular}{|c|c|c|c|c|}
\hline & & & & Lulus \\
\hline 2. & Ilham & 70 & 75 & $\begin{array}{l}\text { Tidak } \\
\text { Lulus }\end{array}$ \\
\hline 3. & $\begin{array}{l}\text { Fatli } \\
\text { Agustri }\end{array}$ & 70 & 75 & $\begin{array}{l}\text { Tidak } \\
\text { Lulus }\end{array}$ \\
\hline 4. & $\begin{array}{l}\text { Ella Safitri } \\
\mathrm{L}\end{array}$ & 76 & 75 & Lulus \\
\hline 5. & $\begin{array}{l}\text { Medya } \\
\text { Oktareva }\end{array}$ & 70 & 75 & $\begin{array}{l}\text { Tidak } \\
\text { Lulus }\end{array}$ \\
\hline 6. & $\begin{array}{l}\text { lqbal } \\
\text { Syamputra }\end{array}$ & 68 & 75 & $\begin{array}{l}\text { Tidak } \\
\text { Lulus }\end{array}$ \\
\hline 7. & $\begin{array}{l}\text { Defri } \\
\text { Yandri }\end{array}$ & 70 & 75 & $\begin{array}{l}\text { Tidak } \\
\text { Lulus }\end{array}$ \\
\hline 8. & $\begin{array}{l}\text { Bambang } \\
\text { Rahmat H }\end{array}$ & 77 & 75 & Lulus \\
\hline 9. & $\begin{array}{l}\text { Hendra } \\
\text { Firdaus }\end{array}$ & 76 & 75 & Lulus \\
\hline $\begin{array}{l}1 \\
0 .\end{array}$ & $\begin{array}{l}\text { Kendry } \\
\text { Pratama }\end{array}$ & 70 & 75 & $\begin{array}{l}\text { Tidak } \\
\text { Lulus }\end{array}$ \\
\hline \multicolumn{2}{|c|}{$\begin{array}{l}\text { Rata-rata hasil } \\
\text { Belajar }\end{array}$} & 71,5 & 75 & $\begin{array}{l}\text { Tidak } \\
\text { Lulus }\end{array}$ \\
\hline
\end{tabular}

\begin{tabular}{|l|c|c|c|}
\hline $\begin{array}{l}\text { Rata-rata hasil } \\
\text { Belajar }\end{array}$ & 81,7 & 75 & Lulus \\
\hline
\end{tabular}

\section{B. Pembahasan}

M-Learning ini telah melalui tahap uji coba validitas, praktikalitas, dan Efektivitas. Pada uji coba validitas dilakukan dengan cara meminta pendapat kepada validator melalui angket. Dari uji coba validitas yang dilakukan didapatkan hasil bahwa M-Learning ini valid digunakan sebagai salah satu media pembelajaran. Uji coba praktikalitas dilakukan dengan cara meminta pendapat kepada dosen PBO dan mahasiswa melalui angket. Dari uji coba praktikalitas yang dilakukan didapatkan hasil bahwa M-Learning ini praktis untuk digunakan sebagai salah satu media pembelajaran. Uji coba Efektivitas dilakukan dengan cara melihat

Tabel 2. Rata-rata hasil belajar mahasiswa setelah menggunakan

\begin{tabular}{|c|l|c|c|c|}
\hline No & $\begin{array}{l}\text { Nama } \\
\text { Mahasis } \\
\text { wa }\end{array}$ & $\begin{array}{c}\text { Hasil } \\
\text { Belaj } \\
\text { ar }\end{array}$ & $\begin{array}{c}\text { KK } \\
\text { M }\end{array}$ & $\begin{array}{c}\text { Keterang } \\
\text { an }\end{array}$ \\
\hline 1. & $\begin{array}{l}\text { Mustiqa } \\
\text { Rahmah }\end{array}$ & 78 & 75 & Lulus \\
\hline 2. & $\begin{array}{l}\text { Miky } \\
\text { Destre S }\end{array}$ & 80 & 75 & Lulus \\
\hline 3. & Nursal & 78 & 75 & Lulus \\
\hline 4. & $\begin{array}{l}\text { Akmal } \\
\text { Miza }\end{array}$ & 80 & 75 & Lulus \\
\hline 5. & $\begin{array}{l}\text { Yulia } \\
\text { Dartika }\end{array}$ & 80 & 75 & Lulus \\
\hline 6. & $\begin{array}{l}\text { Ira } \\
\text { Mustini }\end{array}$ & 80 & 75 & Lulus \\
\hline 7. & $\begin{array}{l}\text { Canri } \\
\text { Tiurmauli }\end{array}$ & 85 & 75 & Lulus \\
\hline 8. & Firdaus & 87 & 75 & Lulus \\
\hline 9. & $\begin{array}{l}\text { Meiliza } \\
\text { Wettaria }\end{array}$ & 89 & 75 & Lulus \\
\hline 10 & $\begin{array}{l}\text { Mulia } \\
\text { Wati }\end{array}$ & 80 & 75 & Lulus \\
\hline & \begin{tabular}{l} 
Wati \\
\hline
\end{tabular} & \multicolumn{2}{|c|}{} \\
\hline
\end{tabular}
perbandingan antara hasil belajar tanpa menggunakan $M$ Learning yang diperoleh dari dosen PBO dengan hasil belajar mahasiswa dengan memberikan soal uji kompetensi setelah menggunakan M-Learning. Dari uji coba Efektivitas yang dilakukan didapatkan hasil bahwa M-Learning ini dapat meningkatkan hasil belajar serta dapat menghemat waktu dan tenaga, maka M-Learning ini merupakan salah satu media yang efektif untuk digunakan sebagai salah satu media pembelajaran.

Hasil penelitian dari penelitian relevan tentang Rancangan dan Pembuatan Mobile Learning Berbasis 
Android (Studi Kasus : Pembelajaran Sejarah Di SMP) mendapatkan hasil bahwa model pembelajaran pembuatan aplikasi multimedia khususnya M-Learning dinilai baik dan dapat meningkatkan kemampuan mahasiswa dalam belajar. Penelitian relevan lainnya tentang Perancangan dan Pembuatan Aplikasi $M$ Learning untuk pembelajaran bahasa Jepang berbasis BREW, hasil penelitian menunjukkan media pembelajaran yang dikembangkan memenuhi kriteria sangat baik dan memberikan manfaat bagi siswa khususnya untuk melakukan belajar mandiri pada mata pelajaran bahasa Jepang. Kelebihan dari pengembangan media pembelajaran di atas adalah pada tahap pengembangannya dilakukan beberapa uji coba yaitu uji coba awal, uji coba lapangan, dan uji coba operasional setelah itu dilakukan perbaikan terhadap media tersebut. Sedangkan kekurangannya adalah pada tahap pengembangannya tidak dilakukan uji coba untuk mencari tahu bagaimana kevalidan, kepraktisan, dan keefektifan dari media pembelajaran tersebut. Pengembangan M-Learning mata kuliah PBO ini mempunyai kelebihan dari penelitian relevan di atas, yaitu dalam proses pengembangannya dilakukan uji coba untuk mencari tahu bagaimana kevalidan, kepraktisan, dan keefektifan dari M-Learning ini sedangkan penelitian relevan di atas tidak ada membahas hal-hal tersebut dalam penelitiannya. Setelah dilakukannya penelitian diperoleh hasil bahwa M-Learning ini merupakan media pembelajaran yang valid, praktis, dan efektif. Peneliti juga memikirkan tentang biaya yang harus dikeluarkan mahasiswa dalam mengakses mobile learning, karena media ini sangat bergantung kepada internet. Berdasarkan pantauan peneliti, setiap mahasiswa yang mempunyai smartphonemereka memiliki kartu GSM khusus untuk smartphone, di mana kartu tersebut sudah menyediakan berbagai paket internet untuk penggunanya dalam mendapatkan akses internet, Sehingga peneliti berkesimpulan bahwa dari segi biaya tidak akan ada penambahan biaya berarti bagi pengguna, selama masih menggunakan smartphone.

\section{Simpulan dan Saran}

\section{A. Simpulan}

1. Hasil rancangan media mobile learning peneliti memilih warna ungu sebagai warna dasar aplikasi, hal ini karena warna ungu adalah warna kebesaran kampus AMIK Boekittinggi.

2. Aplikasi mobile learning dilakukan pengujian validitas, praktikalitas, dan efektivitas dengan hasil:
a) Perancangan
dan pembuatan Mobile learning telah melalui tahap uji validitasoleh 2 orang validator. Berdasarkan hasil 
angket yang telah diisi, untuk validator pertama menunjukkan angka $81,25 \%$ pada derajat pencapaian, sedangkan validator kedua menunjukkan angka $86,25 \%$,dari data yang diperoleh peneliti menyimpulkan bahwa aplikasi mobile learning sudah bisa dianggap valid. Hasil uji validitas menyatakan bahwa Mobile learning ini valid.

b) Perancangan dan pembuatan Mobile learning telah melalui tahap uji praktikalitas yang di lakukanoleh2 orang

dosenpengajarmatakuli ah PBO dan 10 orang mahasiswa yang menggunakan mobile learning. Berdasarkan data yang diperoleh, derajat pencapaian dosen pertama $77,50 \%$ dan dosen kedua $82,50 \%$, sedangkan untuk data dari angket praktikalitas

mahasiswa, diperoleh data derajat pencapaian

menunjukkan angka $81.37 \%$, yang berarti media mobile learning ini dinilai praktis oleh mahasiswa. Sehingga penulis bisa menyimpulkan aplikasi mobile learning praktis untuk pendapat masing-masing dosen dan mahasiswa. Hasil uji praktikalitas menyatakan bahwa
Mobile learning ini praktis.

c) Perancangan dan pembuatan Mobile learning telah melalui tahap uji efektivitas yang diukur dengan hasil belajar. Berdasarkan data hasil belajar mahasiswa yang menggunakan media mobile learning dengan mahasiswa yang tidak menggunakan media mobile learning, terdapat sebuah perubahan nilai yang menunjukkan kearah positif. Dilihat dari ratarata nilai, mahasiswa yang tidak menggunakan media mobile learning menunjukkan angka 71,5 sedangkan ratarata mahasiswa yang menggunakan media mobile learning menunjukkan angka 81,5. Hasil uji efektivitas menyatakan bahwa Mobile learning ini efektif.

\section{B. Saran}

1. Bagi pihak terkait, diharapkan melakukan perancangan yang terencana, sistematis, dan terstruktur. Susunlah rencana perancangan dengan rapi sebelum dilakukan pembuatan Mobile learning. Sehingga akan dihasilkan Mobile learning yang tepatsasaran. Keadaan ini akan berguna ketika dilakukan pengembangan dan 
modifikasi terhadap bagianbagian Mobile learning.

2. Perlu dikembangkan Mobile learning yang berisi materimateri perkuliahan yang lengkap dari seluruh mata kuliah di perguruan tinggi. Selain memperhatikan isi dan konten perlu juga untuk menambahkan penelitian yang berkaitan dengan kecepatan akses Mobile learning dimana dipengaruhi oleh beberapa faktor seperti kecepatan akses internet yang diberikan oleh jaringan operator seluler, serta biaya paket internetnya.

\section{DAFTAR PUSTAKA}

[1] Adri, Muhammad. 2006. Strategi Pengembangan Multimedia Instructional Design. Artikel, diambil pada tanggal 3 Desember 2013, dari http://ilmukomputer.org/wpcont ent/uploads/2008/03/adri_mak asemnas2008.pdf

[2] Apriyanti. 2010. Rintisan Bank Soal Berbasis Ulanngan Kenaikkan Kelas Mata Pelajaran Bahasa Indonesia Untuk SMP. Tesis magister pendidikan, tidak diterbitkan.Universitas Negeri Yogyakarta, Yogyakarta.

[3] Aripurnamayana, M. Irfan. 2011. Rancangan dan Pembuatan Mobile Learning Berbasis Android (Studi Kasus : Pembelajaran Sejarah Di $S M P)$. Jurnal Skripsi Fakultas IImu Komputer Universitas Gunadarma, diambil pada 3
Desember 2013, dari http://repository.gunadarma.ac. id

.[4] Clark N, Quinn. 2011. Designing mLearning Tapping into the Mobile Revolution for Organizational Performance. Preifer. USA

[5] Departemen Pendidikan Nasional. 2008. Kamus Besar Bahasa Indonesia : Edisi Keempat. Balai Pusataka.

[6] Oetomo, Purnomo, Agus. 2006. Pengembangan Bahan Pembelajaran Mandiri Komputasi Fisika Dengan Menggunakan Moodle Secara Online Di Jurusan Fisika Universitas Negeri Semarang. Skripsi sarjana pendidikan. Universitas Negeri Semarang, Semarang

[7] Santyasa, Wayan I. 2007. Landasan Konseptual Media Pembelajaran. Makalah. Jakarta.

[8] Thiagarajan, S., Semmel, D. S \& Semmel, M. I. 1974. Instructional Development for Training Teachers of Expectional Children. Minneapolis, Minnesota: Leadership Training Institute/Special Education, University of Minnesota. 